\title{
Determinants of Competence in Supporting Student's Career Goals
}

\author{
Mahendra Fakhri \\ Department of Business Administration \\ Telkom University \\ Bandung, Indonesia \\ mahendrafakhri@tlkomuniversity.ac.id \\ Ella Virgintia \\ Department of Business Administration \\ Telkom University \\ Bandung, Indonesia
}

\author{
Mahir Pradana \\ Department of Business Administration \\ Telkom University \\ Bandung, Indonesia \\ mahir.pradana@gmail.com \\ Alini Gilang \\ Department of Business Administration \\ Telkom University \\ Bandung, Indonesia
}

\begin{abstract}
Competition among job-seekers are inevitable, competence as a means of supporting career have to be owned by every job seekers. Upcoming ASEAN Free Trade (AFTA) has made the competition even tighter. Therefore, every job-seeker has to increase their competence. University students are included as future job seekers, career as an employee is one of their favorite choice after they graduated from university. The purpose of this research is to understand the dominant factor in determining administration business student competence. A questionnaire is the method used for collecting data from 131 students of business administration using proportionate stratified random sampling technique. Result of the research indicates there are three dominant factors determining administration business student competence, namely communication, strategycreating and self-control.
\end{abstract}

Keywords - Competence, human capital, factor analysis, career goals

\section{INTRODUCTION}

ASEAN Free Trade (AFTA) is a trade agreement between South East Asian countries which provides opportunities and advantages to Indonesian citizen. Competition faced by Indonesia is even bigger when ASEAN economic community becomes official [1]. One of the challenges is how to mobilize and preparing competence for Indonesian workers. According to World Bank report, there are gaps of skills among Indonesian workers who have proper ability in using English language, ability using computer, attitude, critical thinking, and required basic skill [2]. Insufficient skills becomes one of several problems for Indonesian workers, this situation also showed by mostly Indonesian workers are sent abroad as blue collar worker such as domestic worker, caregiver, driver, and factory worker. Meanwhile, other countries sending expert and trained worker to Indonesia as manager or supervisor.
Indonesian worker must prepare their self with set of skills in order to compete with another workers as competitors from other ASEAN countries [3]. Final year student who interested in applying for career as an employee should be ready with competition among other job seekers which come from domestic or abroad. Building competence is one requirement for the purpose [4].

Our focus in this research is the students of Business Administration major at the Faculty of Communication and Business at Telkom University, Indonesia. Here, we focus on last year students who will soon enter the job market. Moreover, the competition of labor is getting tighter with the existence of ASEAN Free Trade (AFTA), consequently each student should have their own competitive competence.

From the results of our early interviews, 10 respondents stated that most students who are about to graduate in want to work first with a reason to seek experience in the world of work even from those already know who want to work where. After gaining experience in the world of work, they want to continue to study their master degree. There are also those who want to start their own business starting from culinary business or in the field of fashion. Therefore, we are looking forward to answer these questions:

1. Which of the competencies of intellectual intelligence, emotional intelligence, and managerial intelligence is the most dominant in the students of Business Administration?

2. How is the competence of intellectual intelligence, emotional intelligence and managerial intelligence in supporting career goals of Business Administration?

Based on the formulation of the problem can be known the purpose of this study is to know which one among intellectual intelligence, emotional intelligence, and managerial intelligence is most prominent for Business Administration students in supporting their career goals? 
The data is gathered throughout the distribution of questionnaires to 131 respondents who are yang Business Administration students. Data analysis techniques used in processing the data is using factor analysis and descriptive analysis.

\section{LITERATURE STUDY}

According to Fakhri et al [4], understanding and meaning of competence is the underlying characteristic of a person related to the effectiveness of individual performance in the work or the basic characteristics of individuals who have a causal relationship or as a cause-effect with the criteria used as a reference, effective or superior performance at work or in certain situations. Dulewicz \& Higgs [5] argued that intellectual competence is a competency that affects one's leadership. In their research they both try to see the influence of intellectual competence on leadership style. Both make three indicators for measuring one's competence related to this intellectual competence, ie in the ability to analyze a problem, critical (critical and analysis judgment), the ability to create a big picture of what he wants to achieve (vision and imagination), as well as the ability to make systematic steps to achieve the goal (strategic prospective).

Emotional intelligence determines our potential to learn practical skills based on five elements: (1) self-awareness (knowing the condition of oneself, joy, resource, and intuition); (2) motivation (managing conditions, impulses, and self resources); (4) empathy (awareness of feelings, needs, and the needs of others), and (5) social skills (skills in arousing the desired response of others) (4) empathy (awareness of feelings, needs, and interests of others) [6].

Furthermore, Nikels and McHug in Turner and Muller [11] attached managerial competence in leadership style. In their research they both try to see the effect of managerial competence on leadership style. According to Simamora [7] career is "The sequence of activities related to work and the behaviors, values, and aspirations of a person during the life span of the person". Career planning is a deliberate process whereby through it one becomes aware of the attributes associated with personal careers and a series of steps throughout life contributes to career fulfillment. According to Pradana [8], "career is a process that deliberately created the company to help employees to help workplace participation.

Factors used by the authors in the study are intellectual intelligence, emotional intelligence, and managerial intelligence. In Intellectual intelligence use research from Dulewicz \& Higgs [5] because the indicators they use can be researched in the students in supporting career goals. Emotional Intelligence here is argued by Goleman [6] because in the indicators they use can be researched in the students in supporting career goals. Some indicators used can be researched in the students in supporting career goals.

\section{METHOD AND DISCUSSION}

Sampling technique in this research is nonprobability sampling. According to Sugiyono [9], nonprobability sampling is a sampling technique that does not give equal opportunities / opportunities for each element or member of the population to be selected to be sampled. Proportionate Stratified Random Sampling Techniques Used when the researcher assumes the population has a large number of members and has different characteristics between the equivalents / levels that exist and the difference can affect the variable. With $95 \%$ confidence level, a sample of 131 people is obtained. The data needed in the research is quantitative data that require primary data. Primary data obtained through the distribution of questionnaires are structured questions that are submitted to the sample based on the decomposition of each variable used in the research model.

In this study, to test the validity of the questionnaire instrument, the researcher will use the help of the Statistic Product and Service Solution (SPSS) 20. According to Sugiyono [9], test the validity in factor analysis by looking at Kaiser-Meyer-Olkin (KMO) and Bartlett's test of sphericity and Anti-Image. Basic decision-making validity test is as follows:

1. KMO to test the feasibility of factor analysis, if the index ranges from 0.5 to 1 then factor analysis is feasible.

2. Bartlett's test of sphericity is a statistical test to test whether the variables / item statements involved are correlated, criteria of significance numbers $<0.05$.

3. Anti-Image Testing is done by considering the value of Measure of Sampling Adequacy (MSA). MSA has the same meaning as the KMO value, it's just partial (every statement item / variable). If the statement / variable item has an MSA value $<0.5$ then the statement / variable item is removed from the matrix and the test is repeated [7]. In the table below explained that the number of KMO and Bartlett's Test of Sphericity is 0.841 with a significance of 0.000 , which means $100 \%$ reliable among variables there is correlation. Since the KMO number is already above 0.5 and the significance is far below $0.05(0.001$ $<0.05)$, the item statement / variable and the existing sample can already be analyzed by factor analysis

TABLE I KMO AND BARTLETT'S TEST OF SPHERICITY KMO AND BARTLETT'S TEST

\begin{tabular}{|lc|r|}
\hline Kaiser-Meyer-Olkin Measure of Sampling Adequacy. &, 841 \\
& Approx. Chi-Square & 590.974 \\
Bartlett's Test of Sphericity & df & 55 \\
& Sig. & .000 \\
\hline
\end{tabular}

According to Santoso [10], if there is more than one variable that has MSA value below 0.5 then that issued is variable with smallest MSA value. Next, the process of testing KMO and Bartlett's test of sphericity and Anti-image remain 
repeated. The table below shows that all MSA values are above 0.5 . This means that 25 items statement / last variable can be done next factor analysis process because it qualifies the value MSA > 0.5 [10].

\section{TABLE II ANTI IMAGE MATRICES}

\begin{tabular}{|c|c|c|}
\hline No. & Variables & MSA \\
\hline 1. & Critical and analytical thinking & .907 \\
\hline 2. & Creating vision & .792 \\
\hline 3. & Reating strategy & .782 \\
\hline 4. & Self-awareness & .894 \\
\hline 5. & Self-control & .724 \\
\hline 6. & Social awareness & .826 \\
\hline 7. & Relationship control & .904 \\
\hline 8. & Communication & .899 \\
\hline 9. & Manajemen waktu & .793 \\
\hline 10. & Task management & .818 \\
\hline 11. & Technicality & .903 \\
\hline
\end{tabular}

In the table above looks 11 items statement / variable is feasible and valid for further analysis. In the above validity process there are also 7 items of invalid statements / variables for further analysis, so the seven items of the statement will not be included in the next factor analysis. Reliability test can be done with coefficient Cronbach's Alpha using the software SPSS [9]. In general, an instrument is said to be reliable if it has a coefficient Cronbach's Alpha $>0.5$ (www.stats.stackexchange.com, 2013).

\section{TABLE III RELIABILITY TEST}

Reliability Statistics

\begin{tabular}{|r|r|}
\hline \multicolumn{1}{|c|}{ Cronbach's Alpha } & \multicolumn{2}{|c|}{ N of Items } \\
\hline .814 & 11 \\
\hline
\end{tabular}

From the table above we can see that the result of reliability test, which is Cronbach's Alpha, in the value of 0.814 , this means the statement items in the questionnaires are reliable.

Data analysis in this study using factor analysis where factor analysis is one of multivariate statistical techniques. The purpose of factor analysis is:

a. Summarization of data to identify the relationship between variables by conducting a correlation test.

b. Data reduction is after a correlation, which undergoes the process of creating a new set of variables called factors to replace a certain number of variables. The type of multivariate analysis used is Principal Components Analysis (PCA). According to Simamora [7], PCA is a statistical approach that can be used to analyze the interrelationship of a large number of variables and to explain what dimensions (called factors) underlie those variables. PCA aims to know the minimum number of extractable factors.

The stages of factor analysis according to Santoso [10] are as follows:

1. Assessing Eligible Variables
The process of evaluating the appropriate variables has been done on the previous validity test, where there are 11 items of statement / variable with KMO $=0.837$ and Bartlett's Test of Sphericity with significant value $=0,000$, and the value of MSA 11 statement items> 0.5 , then 11 items statement / variable and the existing sample can already be analyzed by factor analysis.

2. Factoring process (Extraction Factor) with PCA method

According to Santoso [10], the Total Variance Explained table shows how many factors are formed by taking into account the value of eigenvalues. From the table below shows that only 7 factors are valid, since the 1 factor is its eigenvalue value $\geq 1$. Factors whose eigenvaluenya value $<1$ is not maintained. [11]

TABLE IV TOTAL VARIANCE EXPLAINED TOTAL VARIANCE EXPLAINED

\begin{tabular}{|c|r|r|r|r|r|r|}
\hline $\begin{array}{c}\text { Co } \\
\text { mp } \\
\text { one } \\
\text { nt }\end{array}$ & \multicolumn{3}{|c|}{ Initial Eigenvalues } & \multicolumn{3}{c|}{$\begin{array}{c}\text { Extraction Sums of Squared } \\
\text { Loadings }\end{array}$} \\
\cline { 2 - 7 } & Total & $\begin{array}{c}\text { \% of } \\
\text { Varianc } \\
\text { e }\end{array}$ & $\begin{array}{c}\text { Cumulat } \\
\text { ive } \%\end{array}$ & Total & $\begin{array}{c}\% \text { of } \\
\text { Varianc } \\
\text { e }\end{array}$ & $\begin{array}{c}\text { Cumulat } \\
\text { ive \% }\end{array}$ \\
\hline 1 & 4,720 & 42,907 & 42,907 & 4,720 & 42,907 & 42,907 \\
2 & 1,303 & 11,850 & 54,757 & 1,303 & 11,850 & 54,757 \\
3 & 1,018 & 9,251 & 64,007 & 1,018 & 9,251 & 64,007 \\
4 &, 908 & 8,256 & 72,263 & & & \\
5 &, 728 & 6,615 & 78,878 & & & \\
6 &, 583 & 5,301 & 84,179 & & & \\
7 &, 504 & 4,578 & 88,756 & & & \\
8 &, 432 & 3,929 & 92,685 & & & \\
9 &, 372 & 3,383 & 96,069 & & & \\
10 &, 241 & 2,190 & 98,259 & & & \\
11 &, 192 & 1,741 & 100,000 & & & \\
\hline \multicolumn{6}{|c|}{ Extraction Method: Principal Component Analysis. } \\
\hline
\end{tabular}

After one or more of the factors formed, with a factor containing a number of variables, it may be a difficult variable to be determined to enter into which factor so that the rotation of the factor is formed, thus clarifying the position of a variable, one or another factor. The researcher used the Orthogonal Varimax Rotation method, due to Orthogonal Varimax Rotation, which is done while maintaining the angle of both factors by 900 . The goal is in addition to sharpening the difference in factor loading (ie the correlation value) of each variable for both factors, extracted factor there is no correlation. "The values of factor loading contained in each component are values that indicate the contribution of each variable to each component that is maintained as replacement components that are considered to represent the variables that [7]. Below are the results of grouping of variables into factor after factor rotation. 
TABLE V FACTORS GROUPING

\begin{tabular}{|c|c|c|c|}
\hline $\begin{array}{c}\text { No } \\
\text {. }\end{array}$ & Factors & Variables & $\begin{array}{c}\text { Factor } \\
\text { Loading }\end{array}$ \\
\hline 1. & \multirow{7}{*}{ Factor 1} & Self-awareness & 0,699 \\
\hline 2. & & Social Awareness & 0,588 \\
\hline 3. & & Relationship control & 0,738 \\
\hline 4. & & Communication & 0,739 \\
\hline 5. & & Time management & 0,731 \\
\hline 6. & & Decision making & 0,696 \\
\hline 7. & & Technicality & 0,636 \\
\hline 8. & \multirow{3}{*}{$\begin{array}{l}\text { Factor } \\
2\end{array}$} & $\begin{array}{c}\text { Critical and analytical } \\
\text { thinking }\end{array}$ & 0,734 \\
\hline 9. & & Creating vision & 0,806 \\
\hline 10. & & Creating strategy & 0,816 \\
\hline 11. & Factor 3 & Self Control & 0,781 \\
\hline
\end{tabular}

According to Simamora [7], Interpretation of the name of the factor is done by judgment. Because of its subjective nature, results can be different if the interpretation is done by others. Naming factor used by researchers is surrogate variable. Surrogate variable is a factor naming through a replacement variable that has the highest factor loading contribution to represent another variable in a factor. For example, for factor 1 variable that has the biggest loading factor is decision making (0.749) so that factor is named Decision-making, so next for other factors.

TABLE VI FACTOR NAMING

\begin{tabular}{|c|c|c|c|}
\hline Factor & Factor Names & $\begin{array}{c}\text { Factor } \\
\text { Loading }\end{array}$ & Contribution \\
\hline 1 & Communication & 0,739 & $42,909 \%$ \\
\hline 2 & Strategy creating & 0,816 & $11,845 \%$ \\
\hline 3 & Self Control & 0,781 & $9,254 \%$ \\
\hline & Percentage & \multicolumn{3}{|c|}{$64 \%$} \\
\hline
\end{tabular}

\section{CONCLUSION}

Based on the results of research and analysis that have been done, it can be concluded that can provide answers to the problems formulated in research on intellectual competence factor competence analysis, emotional intelligence, and managerial intelligence in student carreer goals. The conclusion that can be taken based on the results of questionnaires distributed to 131 respondents is that there are 3 dominant factors that affect student communication competence, strategy creation and self-control. Communication factor is the most dominant career goal factor in Business Administration student of Faculty of Communication and Business Telkom University. Communication factors include seven variables: selfawareness, social awareness, relationship control, time management, decision making, technicality, and communication.

\section{REFERENCES}

[1] W. Sachs \& T. Santarius. Fair future: resource conflicts, security and global justice; a report of the Wuppertal Institute for Climate, Environment and Energy, 2014

[2] P. Sparrow, C. Brewster,, \& C. Chung. Globalizing human resource management. Routledge, 2016

[3] M. Pradana \& Y. Riyanto. "Pengaruh Kualitas Website PT. KAI (PERSERO) dengan menggunakan metode Webqual 4.0.” Jurnal Kebangsaan, Vol. 6, pp. 12, 2017

[4] M. Fakhri, M. Aditya \& Pradana. "Factor analysis of work motivation using Maslow's hierarchy of needs: Case study on civil servants at Banten Province's Office of Agriculture and Livestock." In International Conference on Emerging Trends in Academic Research, Vol. 1, pp. 258-274, 2014

[5] V. Dulewicz \& M. Higgs. Can Emotional Intelligence be developed? In Leading with Emotional Intelligence. Springer International Publishing, pp. 51-73, 2016

[6] D. Goleman R. J. \& Emmerling. Leading with Emotion Emotional intelligence predicts success. Leadership Excellence, Vol. 22, pp. 7, 9, 2005

[7] H. Simamora. Manajemen Sumber Daya Manusia, Yogyakarta: STIE YKPN, 2001

[8] M. Pradana. "Pengaruh Gaya Kepemimpinan Terhadap Motivasi Karyawan di Ganesha Operation, Bandung." Jurnal Studi Manajemen dan Bisnis, Vol. 2(1), pp. 2439, 2016

[9] Sugiyono. Statistik untuk Penelitian (Cetakan ke-16). Bandung: Alfabeta, 2012

[10] S. Santoso. Statistik Multivariat: Konsep dan Aplikasi dengan SPSS. Jakarta: PT.Elex Media Komputindo, 2010

[11] Turner, John Rodney, and Ralf Müller. "The project manager's leadership style as a success factor on projects: A literature review." Project Management Institute, 2005. 